\title{
The Effectiveness of Handout Teaching Materials in the Solar System Topic Based on Critical Thinking Skills
}

\author{
Lusia Beti Sumarni ${ }^{1 *}$, Badruzsaufari², Muhammad Zaini ${ }^{3}$ \\ ${ }^{1}$ Masters Program of Natural Sciences Teaching, Lambung Mangkurat University, Banjarmasin, Indonesia \\ ${ }^{2}$ Department of Biology, Faculty of Mathematics and Natural Science, Lambung Mangkurat University, Indonesia \\ ${ }^{3}$ Department of Biology Education, Faculty of Teacher Training and Education, Lambung Mangkurat University, Indonesia
}

DOI: 1 10.36348/jaep.2020.v04i06.003 $\quad$ | Received: 30.05 .2020 | Accepted: 08.06.2020 | Published: 12.06 .2020

*Corresponding author: Lusia Beti Sumarni

\section{Abstract}

This research was conducted to improve the teaching-learning process in the classroom, in the form of improvements to teaching materials used by teachers so far, with the hope that students will be able to think critically in addressing a problem. Improvements were made using the Tessmer development method with the aim of seeing the effectiveness of the handout teaching materials used to solve learning problems. The results showed that the handout teaching material developed proved to be effective based on aspects of classical completeness cognitive learning outcomes with a student achievement rate of $79.16 \%$, critical thinking skills of students at $50 \%$, and student response at $85.69 \%$.

Keywords: Effectiveness, handout teaching materials, critical thinking skills.

Copyright @ 2020: This is an open-access article distributed under the terms of the Creative Commons Attribution license which permits unrestricted use, distribution, and reproduction in any medium for non-commercial use (NonCommercial, or CC-BY-NC) provided the original author and sources are credited.

\section{INTRODUCTION}

Education is the essence of life for personal and community development to face hopes and obstacles for a better future. One component of education is learning, whose main purpose is to fully develop individual talents, to realize creative potential, the achievement of personal goals and personal responsibility for social life in society. So that systematically education and learning are sustainable actions to achieve a better life [1].

Education in Indonesia tends not to experience a significant increase, so that the Indonesian nation has not been able to compete with other countries. The results of the Program for International Student Assessment (PISA) in 2015, stated that Indonesian students' scientific, mathematical, and reading abilities are still relatively low which places Indonesia in the 66th position out of 72 participating countries [2].

The tendency of learning Natural Sciences (IPA) learners only study science as a product, memorizing concepts, theories and laws. Therefore, attitudes, processes, and application competencies to apply knowledge experience difficulties because critical thinking competencies are not honed. According to Budsankom et al., [3] a student with critical thinking skills and active learning will be able to solve problems and make decisions logically.

Wahyuni [4] states that critical thinking skills are related to one's ability to identify, analyze and solve problems creatively and think logically so that they get the right decision. Skills are trained by providing stimuli that require a person to think critically. This is in line with Walker \& Finney [5] states that critical thinking is an intellectual process in conceptualizing, applying, analyzing or evaluating as information obtained from observations, experiences, and reflections.

Zaini [6] said that critical thinking skills are categorized as good if they are able to define problems, make hypotheses, collect, analyze, and make conclusions. The ability to think critically provides the right goal, because someone has thoughts that are always curious. Duron et al., [7] argues that someone who is active in critical thinking always emphasizes questions and problems clearly, and assesses information in a relevant way, uses abstract ideas, thinks logically, and communicates effectively. This is in accordance with the opinion of Bloom [8] that students involved in critical thinking are able to improve thinking skills starting from the smallest to the most complex levels. 
To bring up and improve students' critical thinking skills teaching materials are needed. One form of teaching materials is handouts [9]. Handouts are teaching materials in the form of descriptions from various sources relevant to the material to enrich knowledge [10]. Through teaching materials teachers can easily carry out learning activities and students find it easier to learn [10]. Teaching materials are written according to the learning provisions, evaluation materials and interesting teaching materials for students to learn. According to Pannen \& Purwanto [11] teaching materials are instructional materials that are arranged systematically for teachers and students in learning activities.

Prastowo [9] if teaching materials are available that are varied, innovative and interesting, then there are at least three uses of teaching materials for students, namely (1) learning activities are increasingly interesting; (2) students have the opportunity to learn independently; (3) students easily understand each competency they mastered. Teaching materials developed refer to the structure of teaching materials in general of Depdiknas [10] namely titles, semesters, instructions for learning, achievement of competencies, indicators, supporting information and work procedures, exercises, and assessment.

Prastowo [9] states "handouts are teaching materials sourced from literature that are relevant to the subject matter and facilitate students in the learning process". Characteristics of handout teaching materials include (1). Rich information that provides a more complete frame of mind; (2) teaching media a detailed description of the contents of the handout; (3) Handouts are given before starting the lesson. Handouts are teaching materials that can be said to be practical because the handouts contain material summaries, so students can immediately know the important parts of the material being studied.

The results of the researchers 'initial observations of students at SMPN 4 Karang Intan show the learning process uses package books from certain publishers with a limited number of package books available and students' motivation to obtain textbooks is still low, the use of package books has not been fully used as a learning material students themselves at home, in the learning process students are less active in observing, arguing, analyzing and even concluding a problem so as not to produce students who have critical thinking skills. Walker \& Finney [5] argues that critical thinking is an intellectual process in making concepts, applying, then analyzing, then trying to find other alternatives in solving problems.

The activity of developing students 'critical thinking skills at SMPN 4 Karang Intan needs to be carried out, therefore the authors develop teaching materials in the form of handouts of solar system topics based on students' critical thinking skills developed according to Curriculum 2013. Critical thinking skills are obtained through practical activities, discussions and practice questions to solve the problem of a problem formulation by thinking critically and logically. The research objectives are (1) evaluating the validity of handout teaching materials; (2) evaluates the practicality of handout teaching materials; and (3) evaluating the effectiveness of handout teaching materials. Through handout teaching materials on the topic of the solar system, the science learning process does not only understand natural science concepts, but invites students to think constructively and bring students to interesting, fun learning, challenging students to think and reason to improve thinking skills.

\section{RESEARCH METHODS}

The research method used is a method of learning improvement by focusing on aspects of the effectiveness of learning. This study uses the Tessmer [12] research model which consists of five steps. The five steps are as follows: 1) Self evaluation (self evaluation); 2) expert opinion (expert review); 3) individual trials (one to one); 4) small group trials; and 5) field test.

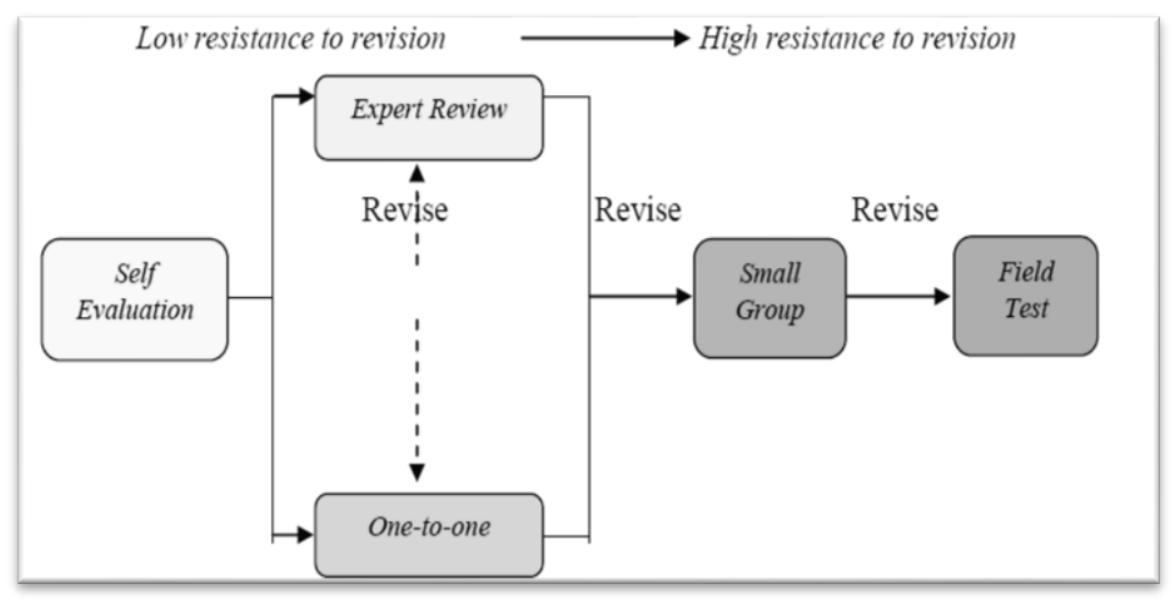

Fig-1: Research Model Flow [12] 


\section{RESEARCH RESULTS AND DISCUSSION}

Initial product improvements include making the cover design so that it shows the existing studies in teaching materials and attracts the attention of students; strengthening materials by sorting materials in more detail and in a complex manner; sentence structuring is made to attract reading interest; arrangement of images made clearer, detailed and attractive colors; and making questions that present HOTS questions that can improve students' critical thinking skills.

From the results of the analysis compiled instructional materials handout solar system topics with systematic consisting of:

1. The design of the cover (cover), interesting against the background of the solar system can arouse interest and attract the attention of students to learn it. As explained by Arsyad [13], that the media chosen in the learning process must also be easily seen and interesting so that students are moved and encouraged to pay attention to the message conveyed through handout teaching materials. Thus the handout teaching material requirements of the solar system based on critical thinking skills developed in terms of covers have been met.

2. Preface contains thanks to God, requests for criticism and suggestions;

3. Contents of handout teaching materials, containing systematic handouts that are supplemented with activity instructions to foster critical thinking, among others, let's think, let's read, let's find out, masri discuss, let's be creative and let's practice.

4. Instructions for the use of teaching materials and Table of contents, containing systematic handouts; compiled contains ways to use teaching materials to facilitate students learning handout teaching materials and foster students' critical thinking power. Presentation of handout teaching materials is equipped with guidelines for the use and content of critical thinking skills handout teaching materials such as let's think to formulate a problem, let's find out to formulate hypotheses and observations, let's read to collect data, let's discuss to collect data and analyze data, be creative to formulate conclusions and let's practice to analyze data and be arranged in such a way; handout teaching materials are made simple and use language that is not too standard making it easier for students to learn it. Presentation in simple language will make the module not boring and will be easy to use, as explained by Sudjana [14] that teaching materials that are easily obtained and easy to use greatly help the tasks of the teacher. Thus the handout requirements developed based on critical thinking skills in terms of the presentation of the handout have been met.

5. List of images, containing the number of images, title and number where the image is located. The pictures presented in the handout teaching materials are mostly with pictures and colors that match the original making it easier for students to learn. This is in line with the opinion of Monica and Laura [15] stating that color images can attract someone's attention rather than black and white images. Arsyad [13] also states that images with true colors are important visual elements to give the impression of separation which can heighten the realism of the object being described, show similarities and differences and create certain emotional responses to students. Thus the handout teaching material requirements developed based on critical thinking skills in terms of the image have been met.

6. Competence of solar system topics.

7. The concept map contains a summary of the subject matter of the solar system.

8. Description of teaching materials on handout topics of the solar system based on critical thinking skills containing material about the solar system, earth's movements, moon's movements, solar eclipses and lunar eclipses which are supplemented with discussion, practice questions, feedback and answer keys. Presentation of complete material in handout teaching materials is very helpful for students to know about the material being learned so that it is easily understood by students. This is confirmed by Angkowati [16] that the development of natural science learning can train critical thinking skills. Fadilah et al., [17] also states that the Guided Inquiry-based learning module is effective enough to improve students' higher-order thinking skills. Thus the handout teaching material requirements developed by the solar system in terms of completeness of the material have been met.

9. The pages in the handout that were developed were found statements that developed students' critical thinking skills. As explained by Lambertus [18] that critical thinking skills need to be trained continuously which can become a habit. Thus the handout teaching material requirements which the topic of the solar system based on critical thinking skills developed have been met.

10. The summary contains a summary of the topics of the solar system;

11. Glossary contains words or terms that are considered new or unfamiliar with their explanations;

12. Bibliography contains sources that are used in making handouts. 
At this initial product development stage, instruments, and practice questions before learning and after learning as a support, are developed to implement handouts to measure students' critical thinking skills.
Effectiveness of Handout Teaching Materials

Data obtained from field tests on VII grade students as many as 24 students. Effectiveness can be seen from the cognitive learning outcomes of students and their critical thinking skills which are described in the following Table 1 and 2 .

Table-1: Student cognitive learning outcomes

\begin{tabular}{|c|c|c|c|c|c|}
\hline \multirow[t]{2}{*}{ No } & \multirow[t]{2}{*}{ Student Name } & \multicolumn{2}{|c|}{ Pre-test } & \multicolumn{2}{|c|}{ Post-test } \\
\hline & & Score & M/NM & Score & M/NM \\
\hline 1 & A.Kholik & 50 & TT & 70 & $\mathrm{~T}$ \\
\hline 2 & A.Zalfigri & 55 & TT & 85 & $\mathrm{~T}$ \\
\hline 3 & Ayu W & 60 & TT & 75 & $\mathrm{~T}$ \\
\hline 4 & Irwan B & 40 & TT & 65 & TT \\
\hline 5 & Lukman N & 35 & TT & 60 & TT \\
\hline 6 & Mardiatus S & 60 & TT & 75 & $\mathrm{~T}$ \\
\hline 7 & Marliana & 65 & TT & 70 & $\mathrm{~T}$ \\
\hline 8 & Miladatul & 55 & TT & 90 & $\mathrm{~T}$ \\
\hline 9 & M.Doni & 35 & TT & 60 & TT \\
\hline 10 & M.Husein & 45 & TT & 65 & $\mathrm{TT}$ \\
\hline 11 & M.Piqhan B & 55 & TT & 80 & $\mathrm{~T}$ \\
\hline 12 & M. Rafik & 65 & TT & 85 & $\mathrm{~T}$ \\
\hline 13 & M.Rahman & 30 & TT & 70 & $\mathrm{~T}$ \\
\hline 14 & M. Riduan & 40 & TT & 70 & $\mathrm{~T}$ \\
\hline 15 & M.Taufiq & 45 & TT & 75 & $\mathrm{~T}$ \\
\hline 16 & Mujib Abas & 50 & TT & 75 & $\mathrm{~T}$ \\
\hline 17 & Nur K & 55 & TT & 75 & TT \\
\hline 18 & Nuril A & 40 & TT & 65 & $\mathrm{~T}$ \\
\hline 19 & Nurul H & 35 & TT & 70 & $\mathrm{~T}$ \\
\hline 20 & Putri Nadia & 45 & TT & 75 & $\mathrm{~T}$ \\
\hline 21 & Repanah & 50 & TT & 80 & $\mathrm{~T}$ \\
\hline 22 & Safiena N & 50 & TT & 85 & $\mathrm{~T}$ \\
\hline 23 & Sifa Wati & 60 & TT & 85 & $\mathrm{~T}$ \\
\hline 24 & Siti Khairiah & 55 & $\mathrm{TT}$ & 65 & $\mathrm{~T}$ \\
\hline \multicolumn{2}{|c|}{ Average } & 48.95 & & 73.74 & \\
\hline \multicolumn{2}{|c|}{ Classical Mastery (\%) } & 0 & & 79.16 & \\
\hline
\end{tabular}

Table-2: Student critical thinking skills

\begin{tabular}{|l|l|l|l|l|l|l|l|l|l|}
\hline No & Rated aspect & Group & \multicolumn{3}{l|}{ Handout } & Mod & Category \\
& & & $\mathbf{1}$ & $\mathbf{2}$ & $\mathbf{3}$ & $\mathbf{4}$ & $\mathbf{5}$ & & \\
\hline 1 & Formulate the problem & 1 & 4 & 4 & 3 & 3 & 3 & 3 & Good \\
& & 2 & 4 & 3 & 4 & 4 & 3 & 4 & Very Good \\
& & 3 & 4 & 4 & 3 & 3 & 4 & 4 & Very Good \\
& & 4 & 3 & 4 & 3 & 3 & 3 & 3 & Good \\
\hline 2 & Formulate a hypothesis (temporary answer) & 1 & 4 & 4 & 4 & 4 & 3 & 4 & Very Good \\
& & 2 & 3 & 4 & 3 & 4 & 3 & 3 & Good \\
& & 3 & 3 & 3 & 3 & 3 & 3 & 3 & Good \\
& & 4 & 4 & 3 & 3 & 4 & 3 & 3 & Good \\
\hline 3 & Designing experiments/observations & 1 & 3 & 4 & 4 & 3 & 3 & 3 & Good \\
& & 2 & 4 & 4 & 4 & 3 & 4 & 4 & Very Good \\
& & 3 & 4 & 4 & 3 & 4 & 4 & 4 & Very Good \\
\hline 4 & Collecting data & 4 & 3 & 3 & 3 & 4 & 3 & 3 & Good \\
& & 1 & 4 & 3 & 4 & 3 & 3 & 3 & Good \\
& & 2 & 4 & 3 & 3 & 4 & 3 & 3 & Good \\
& & 3 & 4 & 3 & 4 & 3 & 4 & 4 & Very Good \\
\hline 5 & Analyze data & 4 & 4 & 3 & 4 & 3 & 4 & 4 & Very Good \\
\hline & & 1 & 3 & 4 & 3 & 3 & 4 & 3 & Good \\
& & 2 & 3 & 4 & 4 & 3 & 4 & 4 & Very Good \\
& & 3 & 4 & 4 & 4 & 3 & 4 & 4 & Very Good \\
\hline 6 & Formulate conclusions & 4 & 4 & 3 & 3 & 4 & 4 & 4 & Very Good \\
\cline { 5 - 8 } & & 1 & 3 & 4 & 3 & 4 & 3 & 3 & Good \\
& & 2 & 4 & 4 & 3 & 4 & 4 & 4 & Very Good \\
& & 3 & 4 & 4 & 4 & 4 & 3 & 4 & Very Good \\
\hline
\end{tabular}


The development of handout teaching materials is declared effective based on data on cognitive learning outcomes and students' critical thinking skills. The results of this study are in line with research conducted by Angkowati [16] that module development is carried out effectively based on cognitive learning outcomes, critical thinking skills, character attitude, social attitude and social response of students. Whereas in Asnida's research [19] only details critical thinking skills, character behavior and social skills are classified as good. Andriani [20]; Fadilah [17]; Imama [21]; Mingle [22]; Setyowati [23] but did not elaborate on cognitive learning outcomes, character attitudes, social attitudes and student response attitudes but only details about critical thinking skills.

\section{CONCLUSION}

Based on the results of research conducted, it can be obtained several vertices that the development of handout teaching materials was declared effective based on data on classical learning completeness cognitive outcomes with an average of $79.16 \%$ and critical thinking skills of students with an average of $50 \%$.

\section{REFERENCES}

1. Fahmi., \& Irhasyuarna, Y. (2019). Pengantar Pendidikan: Manusia, Pendidikan, dan Perkembangan Zaman. Banjarmasin: Program Studi Magister Keguran IPA PPs ULM. Retrieved from http://eprints.ulm.ac.id/8298/

2. OECD. (2016). PISA 2015 Results (Volume II): Policies and Practices for Successful Schools. Paris: OECD Publishing.

3. Budsankom, P., Sawangboon, T., Damrongpanit, S., Chuensirimongkol, A. (2015). Factors Affecting Higher Order Thinking Skills of Students: A Meta-analytic Structural Equation Modeling Study. Academic Journal, 10(19):26392652.

4. Wahyuni, S. (2011). Mengembangkan Keterampilan Berpikir Kritis Siswa Melalui Pembelajaran IPA Berbasis Problem Based Learning. In: Seminar Nasional FMIPA-UT 2011.

5. Walker, P., \& Finney, N. (1999). Skill Development and thinking In Higher Education. Teacher in Higher Education, 4(4):531-547.

6. Zaini, M. (2018). Penelitian Desain Pendidikan Aplikasi Teori ke Dalam Praktik. Banjarmasin: Universitas Lambung Mangkurat Press.

7. Duron, R., Limbach, B., \& Waugh, W. (2006). Critical Thinking Framework for Any Discipline. International Journal of Teaching and Learning in Higher Education, 2006, Volume 17, Number 2.

8. Filsaime, D. K. (2008). Menguak Rahasia Berpikir Kritis dan Kreatif. Jakarta: Prestasi Pustaka.

9. Prastowo, A. (2012). Panduan Kreatif Membuat Bahan Ajar Inovatif. Jogjakarta: DIVA Press.

10. Depdiknas. (2008). Penulisan Modul. Jakarta: Direktorat Tenaga Kerja kependidikan. Direktorat
Jendral Peningkatan Mutu Pendidikan dan Tenaga Kependidikan Departemen Pendidikan Nasional.

11. Pannen., \& Purwanto. (2001). Penulisan Bahan Ajar. Jakarta: Pusat Antar Universitas untuk Peningkatan dan Pengembangan Aktivitas Instruksional Ditjen Dikti Dinas.

12. Tessmer, M. (1998). Planning and Conducting Formative Evaluation. London: Kogan Page.

13. Arsyad, A. (2010). Media Pembelajaran. Jakarta: PT. Rajagrafindo persada.

14. Sudjana, N. (2004). Metode Penenlitian Kuantitatif Kualitatif dan $R \& D$. Bandung Alfabet

15. Monica., \& Laura, C. L. (2011). Construct Validity in Psychological Tests Humaniora. 2(2):1084-1096.

16. Angkowati J. (2018). Pengembangan Modul Pembelajaran IPA Kelas VIII untuk Melatih Keterampilan Berpikir Kiritis Siswa SMP. Tesis Magister Keguruan IPA Universitas Lambung Mangkurat.Banjarmasin, Tidak dipublikasikan.

17. Fadilah, S. I., Soeparman, K., \& Imam, S. (2015). Pengembangan Perangkat Pembelajaran Biologi Berbasis Inkuiri Materi Sistem Ekresi Manusia untuk Melatih Keterampilan Berpikir Kritis dan Kerjasama Siswa SMA. Jurnal Pendidikan Sains Pascasarjana Universitas Negeri Surabaya. 5(1).

18. Lambertus. (2009). Pentingnya Melatih Keterampilan Berpikir Kritis dalam Pembelajaran Matematika di SD. Jurnal Forum Kependidikan Nomor 2 Volume 28 maret 2009. Kendari: FKIP Unhalu.

19. Asnida, J. D. (2014). Pengembangan Perangkat Pembelajaran dan Modul Biologi untuk Siswa SMP Negeri 3 Sungai Loban. Tesis Magister Pendidikan Biologi Universitas Lambung Mangkurat. Banjarmasin, Tidak dipublikasikan.

20. Andriani, D. (2017). Pengembangan Modul Pembelajaran Biologi Berbasis Keterampilan Berpikir Kritis Siswa Kelas X di Sekolah Menengah Atas. Tesis. FKIP Universitas Lampung.

21. Imama, N. A. (2014). Pengembangan Modul Berbasis Greening School Konsep Klasifikasi Tumbuhan di SMK 1 Tangkisung. Tesis Magister Pendidikan Biologi Universitas Lambung Mangkurat. Banjarmasin, Tidak dipublikasikan.

22. Mingle. (2015). Pengembangan Modul IPA Berbasis PBL untuk Meningkatkan Kemampuan Memecahkan Masalah pada Materi Polusi serta Dampaknya pada Manusia dan Lingungan Siswa Kelas XI SMKN Pancasila Purwodadi. Perpustakaan uns.ac.id. Diakses tanggal 01 Januari 2016.

23. Setyowati, T. (2013). Pengembangan Perangkat Pembelajaran IPA SMP Menggunakan Model Inkuiri Topik Klasifikasi Makhluk Hidup. Tesis Magister Pendidikan Biologi Universitas Lambung Mangkurat. Banjarmasin, Tidak dipublikasikan. 